\title{
Bullying, social skills, peer acceptance, and friendship among students in school transition
}

\author{
Bullying, habilidades sociais, aceitação pelos pares e \\ amizade de estudantes em transição escolar
}

\author{
Jorge Luiz da SILVA ${ }^{1}$ iD) 0000-0002-3727-8490 \\ André Vilela KOMATSU2 (ID) 0000-0001-8508-6787 \\ Marcela Almeida ZEQUINÃO3 ${ }^{3}$ iD 0000-0003-3570-5425 \\ Beatriz Oliveira PEREIRA4 (ID) 0000-0003-4771-9402 \\ GuoYong WANG5 ${ }^{5}$ iD) 0000-0002-8308-4443 \\ Marta Angélica lossi SILVA ${ }^{6}$ iD 0000-0002-9967-8158
}

\begin{abstract}
This study's objective was to assess the social skills, peer acceptance, and friendship among students involved in bullying situations transitioning from elementary to middle school. A total of $4086^{\text {th }}$ grade students from six public schools in the interior of São Paulo, Brazil composed the sample; 54.9\% of whom were aged 11.3 years on average (Standard Deviation $=0.6$. Data were analyzed using Analysis of Variance and Spearman's correlation. In regard to social skills, bully-victims present a greater amount of passive and active responses when compared to victims, bullies, and not
\end{abstract}

1 Universidade de Franca, Departamento de Saúde, Programa de Pós-Graduação em Promoção de Saúde. Av. Dr. Armando de Salles Oliveira, 201, Parque Universitário, 14404-600, Franca, SP, Brasil. Correspondência para/Correspondence to: J.L. SILVA. E-mail: <jorge.silva@unifran.edu.br>.

2 Universidade de São Paulo, Faculdade de Filosofia, Ciências e Letras, Programa de Pós-Graduação em Psicologia. Ribeirão Preto, SP, Brasil.

${ }^{3}$ Universidade do Estado de Santa Catarina, Faculdade de Saúde e Ciências do Esporte, Departamento de Educação Física. Florianópolis, SC, Brasil.

${ }^{4}$ Universidade do Minho, Centro de Investigação em Estudos da Criança, Programa de Pós-Graduação em Estudos da Criança. Braga, Portugal.

5 Universidade Marítima de Shanghai, Faculdade de Artes e Ciências, Departamento de Educação Física. Shanghai, China.

6 Universidade de São Paulo, Escola de Enfermagem, Programa de Pós-Graduação Enfermagem em Saúde Pública. Ribeirão Preto, SP, Brasil.

Support: Fundação de Amparo à Pesquisa do Estado de São Paulo (Processes n 2013/22361-5, 2015/01794-6).

$\checkmark \mathbf{v}$

Como citar este artigo/How to cite this article

Silva, J. L., Komatsu, A. V., Zequinão, M. A., Pereira, B. O., Wang, G.-Y., \& Silva, M. A. I. (2019). Bullying, social skills, peer acceptance, and friendship among students in school transition. Estudos de Psicologia (Campinas), 36, e180060. http://dx.doi.org/10.1590/1982-0 $275201936 \mathrm{e} 180060$ 
involved students. Only male bully-victims, however, experienced significantly more frequent rejection by peers, while female bully-victims had significantly fewer friends. The results indicate the need to develop interventions intended to prevent and decrease bullying in the period of school transition. Such interventions should, however, be gender-sensitive because of differences existing between boys and girls.

Keywords: Bullying; Friends; Rejection (Psychology); Social desirability; Social skills.

\section{Resumo}

O objetivo deste estudo foi avaliar as habilidades sociais, aceitação pelos pares e amizade de estudantes em transição escolar envolvidos em situações de bullying. Participaram 408 estudantes do sexto ano do Ensino Fundamental, de seis escolas públicas do interior do estado de São Paulo, Brasil, 54,9\% do sexo feminino, idade média de 11,3 anos (Desvio Padrão $=0,6$ ). Os dados foram analisados mediante Análises de Variância e correlação de Spearman. Em relação às habilidades sociais, as vítimas agressoras apresentaram maior quantidade de respostas passivas e de respostas ativas em comparação com as vítimas, agressores e não envolvidos no bullying. Entretanto, somente os meninos vítimas agressoras foram significativamente mais rejeitados pelos pares e as meninas vitimas agressoras tiveram significativamente menos amigos. Os resultados indicam a necessidade do desenvolvimento de intervenções objetivando prevenir e reduzir o bullying no período de transição escolar, intervenções que sejam sensíveis ao gênero, em função das diferenças identificadas.

Palavras-chave: Bullying; Amigos; Rejeição (Psicologia); Desejabilidade social; Habilidades sociais.

Intentional and repetitive violence that takes place among peers and involves an imbalance of power between victim and aggressor is called bullying (Olweus, 2013). It may occur in different places, but school is where it most frequently takes place during childhood and adolescence (Silva, Oliveira, Bazon, \& Cecilio, 2013). The prevalence of school bullying in Brazil is approximately 28.0\% (Mello et al., 2017), which is considered high when compared to other countries, such as Sweden (9.7\%), Israel (15.1\%), Spain (17.4\%), Italy (19.6\%), and the United States (24.5\%) (Due et al., 2009). Bullying may be expressed through physical, verbal or relational aggression (Sampaio et al., 2015).

Bullying negatively affects the school environment and the development of all those involved in its dynamics: victims, bullies, and bully-victims. Specifically, the following conditions are associated with bullying: depression, anxiety, insecurity, loneliness, learning difficulties, juvenile delinquency, and suicide (Salgado, Senra, \& Lourenço, 2014; Silva \& Bazon, 2014; Silva et al., 2016a; Zequinão et al., 2017). The consequences of bullying, however, also affect students not directly involved with it but who witness violence against peers, namely, bystanders (Silva et al., 2013). Exposure to violence leads individuals to experience a feeling of insecurity that may encourage bystanders to start bullying as a way of self-preservation, thus, intensifying violence. Bullying may also lead students to avoid school, to absenteeism, dropout, and beliefs that violence is an efficient strategy to resolve conflicts (Janosz et al., 2008).

In the same way in which the negative consequences of bullying go beyond the victim-bully pair, the way it occurs also involves the participation of classmates or schoolmates who, even though do not practice violence, may actively (e.g., applauding or laughing at the victim) or passively (e.g., not defending the victim) reinforce the behavior of bullies (Yang \& Salmivalli, 2015). Therefore, how well victims are socially accepted by peers and the amount of friends they have are important aspects determining whether they will be supported or abused. Friends provide support not only during victimization but also when they prevent future victimization, considering that students with friends spend less time alone and are less vulnerable to bullies (Jia \& Mikami, 2015).

Friendship is important for the development of social skills among victims and prosocial behavior among bullies, considering that social skills facilitate social life, an individual's problem-solving capacity, the 2 advocacy of and respect for rights in interpersonal relationships (Z.A.P. Del Prette \& Del Prette, 2013). For 
instance, a friendship established between a victim and a bystander, in addition to favoring a non-violent interaction between them, also encourages the bystander's friends to socially accept the victim. The victims, however, generally present poor social skills that hinder the establishment and maintenance of friendships. In general, victims are anxious, shy, submissive and insecure (Silva et al., 2016b). On the other hand, having a victim as a friend may harm the social acceptance of bystanders. Additionally, bystanders may become the target of bullying themselves and that is why students tend to avoid victims (Kochel, Ladd, Bagwell, \& Yabko, 2015). Bully-victims, in turn, may have even fewer friends and be more frequently rejected by peers, because in addition to their problems related to poor social skills, they also present poor emotional regulation. They are unable to use assertive coping strategies against bullying so they respond aggressively and may become bullies toward those with less power (Silva et al., 2016b).

Peers may accept bullies when they use violence to raise their social status, which requires higher levels of social skills (Kochel et al., 2015). Some bullies however, may present under-developed social skills, which imply difficulties in dealing with interpersonal challenges using non-violent strategies. Hence, improving social skills, especially empathy, has the potential to reduce aggressions (Stan \& Beldean, 2014). Note that friendship and peer acceptance may differentiate bullying not only in terms of social skills, but also in regard to the sex of the participants. For instance, aggressive behavior may be considered typical of boys and be more easily acceptable, not harming the social acceptance of male bullies, while aggressive behavior might be considered deviant among girls, worsening the peer rejection of female bullies (Kochel et al., 2015).

The relationship between bullying, social skills, and peer acceptance may be intensified when students are transitioning between school levels, especially when transitioning from elementary to middle school, which generally implies changing schools, an increased number of school subjects, changes in the way teachers interact with students, and the need to establish friendships with new students (Santos \& Soares, 2016). In this context, for example, poor social skills may hinder the establishment of friendships, lead to peer rejection, and hinder the appropriate resolution of conflicts and self-defense. Taking part in bullying may lead to social rejection and isolation. Having few friends or being in social isolation may lead students to become easy targets for bullies. Thus, this study's objective was to assess the social skills, peer acceptance and friendships of students involved in bullying who are transitioning from elementary to middle school.

\section{Method}

\section{Participants}

Data were collected in six public state schools in the city of Ribeirão Preto, Brazil located in the interior of São Paulo, Brazil. A total of 408 6th grade students participated in the study: $54.9 \%$ were girls and $45.1 \%$ were boys, aged 11.3 years old ( $S D=0.6$ years) on average, ranging between 10 and 12 years. Most participants (92.6\%) had never failed to pass a school grade. In regard to socioeconomic status, $64.2 \%$ belonged to classes B2 and C 1 (Associação Brasileira de Empresas de Pesquisa, 2015). The students reported being of mixed race $(46.1 \%, n=188)$, Caucasian $(40.9 \%, n=167)$, Afro-descendant $(6.1 \%, n=25)$, Asiandescendent $(4.9 \%, n=20)$ and Indigenous $(2.0 \%, n=8)$.

\section{Instruments}

Escala de Vitimização e Agressão entre Pares (EVAP, Aggression and Peer Victimization Scale) (Cunha, Weber, \& Steiner Neto, 2009). The EVAP is an 18-item instrument that takes approximately five minutes to complete. The participants are supposed to check the frequency with which they perpetrate physical, verbal 
and/or relational violence and whether they were targets of such behavior. For instance: "I pushed, punched and/or kicked other students"; "I was pushed, punched and/or kicked by other students"; "I cursed at other students"; "I was cursed at by other students". Answers are provided on a Likert Scale (never; almost never; sometimes; almost always; and always) and allow the profile of students to be established in terms of bullying, whether they were victims, bully-victims, bullies or not involved. The EVAP can be applied from 6th to 12th grade students. Psychometric analysis indicates internal consistency for victimization and bullying ranging from 0.72 and 0.81 (Cronbach's alpha).

Sistema Multimídia de Habilidades Sociais para Crianças (SMHSC, Multimedia System for Children's Social Skills) (A. Del Prette \& Del Prette, 2005). The SMHSC is a computerized self-report instrument composed of 21 videos depicting children socially interacting with other children and adults. Each situation presents another three short videos depicting alternative behavioral responses for the situation presented in the main video, namely: skillful (e.g., showing civility, empathy and assertiveness); passive non-skillful (e.g., running away instead of standing up to situations); and active non-skillful (e.g., being aggressive, ironic, and authoritative). The children are supposed to assess how appropriate the responses are (skillful, passive non-skillful or active non-skillful) for each behavioral video, the frequency with which they usually respond in those ways, and how difficult it is to respond in a socially skillful manner. The instrument can be applied to children up to 12 years old. The instrument takes approximately 35 minutes to be completed and presents an internal consistency (Cronbach's alpha) of 0.64 .

Escala Sociométrica (Sociometric Scale) (Martins, 2009). Instrument composed of 10 items and can be applied to school-aged children and adolescents to investigate social acceptance. Social acceptance is verified by children nominating three classmates they like the most to hang around, play with, talk to or do homework with, while social rejection is verified by students nominating three classmates they like the least to hang around, play with, talk to, or do homework together. The remaining items on the scale $(n=8)$ ask the respondents to nominate one classmate that presented one of the following characteristics: has many friends; has few friends; relates well with teachers; is capable of resolving conflicts; is aggressive; has difficulty expressing him/herself (thoughts and feelings); is nice to schoolmates; and is shy. The scale takes approximately seven minutes to complete. The first individuals nominated in each item concerning social acceptance or rejection scores three points, the second scores two and the third scores one. Those chosen in the remaining items score one each.

\section{Procedures}

After approval was obtained from the Institutional Review Board at the University of São Paulo at de Ribeirão Preto, College of Nursing (Opinion report 18/2015), all the $6^{\text {th }}$ grade students attending the six schools in the sample were invited to participate in the study. A total of 408 students, out of the 522 eligible ones, consented and signed an assent form and presented free-and-informed consent forms signed by their parents or legal guardians. The 408 participants answered the EVAP, SMHSC, and the Sociometric Scale during regular school hours. The researchers explained how to complete the three instruments and were available to clarify any doubts during application. Each class took approximately 30 minutes to complete the instruments.

Data were first described in terms of frequency, percentage, mean and standard deviation. Cluster analysis was performed considering the answers provided to the EVAP, according to Ward's hierarchical method (Seidel, Moreira Júnior, Ansuj, \& Noal, 2008), in order to establish the profile of students in terms of 4 their involvement (or non-involvement) with bullying, that is, whether they were victims, bully-victims, bullies, 
or not involved. Analysis of Variance (ANOVA) was used to identify differences in the dependent variables according to the students' bullying profiles, followed by Bonferroni posttest to identify groups that presented statistical differences. Spearman's coefficient of correlation was calculated to verify the relationships between social skills variables, sociometric variables, and the role played in bullying. All these analyses were performed using IBM ${ }^{\circledR}$ SPSS ${ }^{\circledR}$ Statistics (version 22.0), considering a significance level established at $5 \%, p<0.05$.

\section{Results}

A total of $59.1 \%$ of the students were involved with bullying: $33.1 \%$ were bullies, $14.5 \%$ were victims and $10.5 \%$ were victim-bullies. Boys were more frequently bullies $(57.0 \%)$ and bully-victims $(51.2 \%)$, while girls were more frequently victims (64.4\%) or not involved with bullying (62.6\%). The results concerning social skills and sociometric variables are presented in Table 1.

ANOVA reveals in Table 1 that boys significantly differed in two variables: active responses $(F=4.824$, $p=0.003$ ) and peer rejection $(F=2.837, p=0.40$ ). The Bonferroni posttest reveals that bully-victims (highest mean) and victims ( $p=0.03$ ) differed in terms of active responses, while bully-victims also differed from not involved with bullying students $(p=0.04)$. Bully-victims were also more frequently rejected and significantly differed from not involved with bullying students $(p=0.05)$.

Table 1

Comparison of means obtained by victims, victim-bullies, bullies and not involved with bullying in regard to social skills and sociometric variables

\begin{tabular}{|c|c|c|c|c|c|c|c|c|c|c|}
\hline & \multicolumn{2}{|c|}{$\begin{array}{l}\text { Victims } \\
(n=59)\end{array}$} & \multicolumn{2}{|c|}{$\begin{array}{c}\text { Bully-victims } \\
(n=43)\end{array}$} & \multicolumn{2}{|c|}{$\begin{array}{c}\text { Bully } \\
(n=135)\end{array}$} & \multicolumn{2}{|c|}{$\begin{array}{l}\text { Not involved } \\
\quad(n=171)\end{array}$} & \multicolumn{2}{|c|}{ ANOVA } \\
\hline & $M$ & $S D$ & $M$ & $S D$ & $M$ & $S D$ & $M$ & $S D$ & $F$ & $p$ \\
\hline \multicolumn{11}{|c|}{ Skillful } \\
\hline Boys & 1.35 & 0.35 & 1.43 & 0.25 & 1.30 & 0.29 & 1.31 & 0.28 & 0.942 & 0.422 \\
\hline Girls & 1.38 & 0.30 & 1.35 & 0.23 & 1.35 & 0.28 & 1.33 & 0.29 & 0.147 & 0.932 \\
\hline \multicolumn{11}{|c|}{ Passive } \\
\hline Boys & 0.63 & 0.28 & 0.74 & 0.29 & 0.75 & 0.22 & 0.69 & 0.30 & 1.420 & 0.240 \\
\hline Girls & 0.75 & 0.20 & 0.89 & 0.27 & 0.71 & 0.20 & 0.61 & 0.24 & 9.953 & 0.000 \\
\hline \multicolumn{11}{|c|}{ Active } \\
\hline Boys & 0.38 & 0.28 & 0.72 & 0.47 & 0.68 & 0.39 & 0.47 & 0.35 & 4.824 & 0.003 \\
\hline Girls & 0.64 & 0.29 & 0.74 & 0.38 & 0.56 & 0.38 & 0.33 & 0.27 & 15.077 & 0.000 \\
\hline \multicolumn{11}{|c|}{ Acceptance } \\
\hline Boys & 4.10 & 3.65 & 2.64 & 2.75 & 4.29 & 3.68 & 4.31 & 3.50 & 1.414 & 0.240 \\
\hline Girls & 5.24 & 3.57 & 4.50 & 3.72 & 6.10 & 4.37 & 4.93 & 3.54 & 1.488 & 0.219 \\
\hline \multicolumn{11}{|c|}{ Rejection } \\
\hline Boys & 3.00 & 2.54 & 6.60 & 8.94 & 4.61 & 5.89 & 3.04 & 3.77 & 2.837 & 0.040 \\
\hline Girls & 2.47 & 3.79 & 4.81 & 6.00 & 3.02 & 4.45 & 2.64 & 3.15 & 1.959 & 0.121 \\
\hline \multicolumn{11}{|c|}{ Many friends } \\
\hline Boys & 0.86 & 1.59 & 0.14 & 0.47 & 0.82 & 1.50 & 0.73 & 1.57 & 1.352 & 0.259 \\
\hline Girls & 1.21 & 1.51 & 1.04 & 1.60 & 0.85 & 1.67 & 0.77 & 1.98 & 0.636 & 0.592 \\
\hline \multicolumn{11}{|c|}{ Few friends } \\
\hline Boys & 0.67 & 1.15 & 1.31 & 2.12 & 0.75 & 1.38 & 0.95 & 1.79 & 0.865 & 0.460 \\
\hline Girls & 0.37 & 0.71 & 1.29 & 1.95 & 0.29 & 0.86 & 0.64 & 1.10 & 4.740 & 0.003 \\
\hline
\end{tabular}

Note: F: F-ratio; M: Mean; SD: Standard Deviation; $p=0.05$ 
For the girls, statistical significance was found in terms of passive responses ( $F=9.953, p<0.001)$ when comparing bully-victims (highest mean) with not involved with bullying students ( $p<0.001)$, bully-victims with bullies ( $p=0.03$ ), and victims with not involved with bullying students ( $p=0.01$ ). The female groups also significantly differed in terms of active responses $(F=15.077, p<0.001)$ with differences between not involved with bullying students (lowest mean) and the other three groups: bully-victims $(p<0.001)$, victims $(p<0.001)$, and not involved with bullying students $(p<0.001)$. In regard to the variable few friends, the significant difference between groups $(F=4.74, p=0.003$ ) was located between bully-victims (highest mean) and the groups of bullies $(p=0.003)$ and victims $(p=0.02)$. Table 2 presents the correlations between bullying and victimization with the sociodemographic variables and social skills.

Spearman's correlation indicates that victimization among boys was positively and significantly correlated with skillful responses, suggesting that the greater amount of skillful responses, the greater victimization is, and vice-versa. Victimization was negatively correlated with acceptance; that is, the greater the victimization, the lower the acceptance, and vice-versa. Among boys, bullying was positively and significantly correlated with active responses and many friends. Among girls, victimization was positively correlated with passive responses, active responses and many friends. Bullying was positively and significantly correlated with active responses and many friends, and negatively correlated with passive responses and few friends.

Table 2

Spearman's correlations between bullying and victimization and sociometric variables and social skills

\begin{tabular}{llllllll}
\hline & Skillful & Passive & Active & Acceptance & Rejection & Many friends & Few friends \\
\hline Victimization & & & & & & & \\
Boys & $0.189^{*}$ & 0.008 & 0.052 & $-0.150^{*}$ & 0.099 & -0.113 & 0.025 \\
Girls & 0.095 & $0.349^{* *}$ & $0.425^{* *}$ & 0.058 & 0.001 & $0.179^{* *}$ & -0.039 \\
Bullying & & & & & & $0.194^{*}$ & -0.124 \\
Boys & -0.070 & 0.120 & $0.468^{*}$ & 0.078 & 0.065 & $0.240^{* *}$ & $-0.152^{*}$ \\
Girls & -0.014 & 0.122 & $0.585^{* *}$ & 0.039 & 0.024 & & \\
\hline
\end{tabular}

Note: ${ }^{*} p<0.05 ;{ }^{* *} p<0.001$.

\section{Discussion}

In this study, the prevalence of involvement with bullying was $59.1 \%$, a result that is similar to the findings reported by other Brazilian studies using non-representative samples (Bandeira \& Hutz, 2012; Souza, 2013), though it is above the national mean of $28.0 \%$ (Mello et al., 2017) and a mean of $26.0 \%$ identified in 40 European countries and countries in North America (Craig et al., 2009). A potential explanation for the higher level of bullying identified in this study is school transition, which generally implies that adolescents experience difficulties establishing new friendships and adapting to a new school (Santos \& Soares, 2016; Silva et al., 2013). Another explanation is that variation in terms of prevalence is due to conceptual and methodological differences existing among studies, considering there is no single definition of bullying or a consensus regarding how many times aggression should occur to be considered bullying (Alckmin-Carvalho, Izbicki, Fernandes, \& Melo, 2014). Additionally, a greater number of boys are identified as bullies and 6 bully-victims in other studies (Mello et al., 2017; Bandeira \& Hutz, 2012). This may be explained by demands 
of a cultural nature, such as a need for boys to portray a masculine image, one of domination and power, which encourages boys to be more aggressive in their social interactions (Oliveira et al., 2016).

Bully-victims were more frequently rejected by their peers and had fewer friends when compared to victims, bullies and not involved with bullying students. These results are expected since various empirical studies and literature reviews report that bully-victims are at a greater risk of suffering social rejection and developing psychosocial problems because they exhibit impulsive and disorganized behavior, in addition to facing more behavioral, school and family problems (Brank, Hoetger, \& Hazen, 2012; Lodder, Scholte, Cillessen, \& Giletta, 2016; Silva et al., 2018). This study confirms reports in the literature that bully-victims have poorly developed social skills (Hussein, 2013), as both male and female bully-victims, addressed here, more frequently presented both passive and active (aggressive) responses. These two types of responses may be related to high levels of victimization and bullying perpetrated by bully-victims. Passively responding to bullying indicates a lack of self-defense skills, which may lead to increased levels of bullying to be faced over time (Silva et al., 2016b). These results reveal that this is a concern, especially for female bully-victims and victims. On the other hand, aggressive responses are also inappropriate because they usually lead to equally aggressive reactions (Silva et al., 2018).

Even though bully-victims face greater problems establishing social interaction with school peers, only boys were significantly rejected with greater frequency by their peers compared to not involved with bullying students. Other studies also identified that bully-victims are not favored by their peers (Kochel et al. 2015; Shin, 2010). A potential explanation is that impulsive behavior and difficulty regulating emotions are not appreciated by other students because these lead to aggressive responses even in non-aggressive contexts (Jia \& Mikami, 2015). Therefore, bully-victims may be rejected because they are considered unpleasant company, lacking the necessary conditions to offer appropriate social and emotional support (Kochel et al., 2015). Additionally, peer rejection generally implies a small number of friends, a situation that was confirmed by this study's results; however, significant levels of peer rejection were found only for female bully-victims compared to victims and bullies. Friends are important sources of protection and can serve as a prosocial behavior model, especially for girls, who more frequently defend peers against bullying (Batanova, Espelage, \& Rao, 2014).

Passivity and aggressiveness are predictors of victimization (Silva et al., 2016b); boys, though, presented a significant correlation between victimization and skillful responses. This result is explained by the fact that when bullying is considered a group phenomenon, it is influenced by the norms established by the peer context and by the behavior of not involved with bullying students, who may defend the victim or reinforce the behavior of bullies (Yang \& Salmivalli, 2015). Therefore, even the skillful responses from victims may be ineffective in a context in which aggression is considered to be normal, especially in the interactions among boys, who tend to be more aggressive (Oliveira et al., 2016). Having the support of friends who stand up for their peers, is important in a context of bullying, which seems not to happen with the girls participating in this study, given that victimization among girls was correlated with having many friends. This may mean that female victims or bully-victims have friends who lack the conditions to defend them, perhaps because they are themselves victims (Jia \& Mikami, 2015). Another possible explanation is potential gender differences between the nature of aggression perpetrated by boys and girls. Girls generally attack their own friends, while boys tend to be more aggressive with those who they are not their friends (Grotpeter \& Crick, 1996).

The relationship between bullying and having many friends is confirmed by various studies for both boys and girls (Jia \& Mikami, 2015; Kochel et al., 2015), including a study conducted in the United States addressing a nationally representative sample of 6th to 9th grade students (Nansel et al., 2001). There are indications that bullies do not lack social skills, as they are skillful in manipulating people and situations to their benefit, but they have poorly developed moral standards (Gasser \& Keller, 2009). Hence, they can use bullying as a way to obtain greater social status and popularity, however, in a way their peers do not reject 
them. At the same time, their friends may reinforce bullying as they either support bullies or do not defend the victims. Salmivalli (2010) identified that, even though most students disapprove of bullying, approximately $80 \%$ of them actively or passively support bullies in a real context of bullying. For this reason, schools need to encourage not involved with bullying students to take a stand against bullying, disapproving the behavior of bullies as a strategy to decrease bullying. By taking a stand against bullying, not involved with bullying students provide a model of prosocial conduct for bullies, directly or indirectly showing them more adaptive forms of social interaction (Jia \& Mikami, 2015).

Some limitations should be considered when interpreting these results. The first is the sample size, composed only of public schools, which prevents the generalization of results. Future studies with similar objectives can use larger and representative samples including public and private schools. The second limitation is that results do not allow for the establishment of causal relationships. Longitudinal studies are needed to identify cause and effect relationships between bullying, social skills, peer acceptance and friendship. The third limitation that can be overcome in future studies is that the instrument used to collect data does not measure cyber bullying, that is, aggressions that take place via aggressive or vexatious messages disseminated through mobile phones, e-mails, social networks or websites. Despite limitations, this study's results contribute to clarifying differences between victims, bullies, bully-victims and not involved with bullying students in terms of social skills, peer acceptance, and friendships among boys and girls attending public schools. The results indicate a need to develop interventions to prevent and decrease bullying during school transition. Such interventions should be gender sensitive and consider the differences identified between boys and girls.

\section{Contributors}

J.L. SILVA, A.V. KOMATSU and M.A. ZEQUINÃO contributed to the planning of the study, performed the statistical analysis and wrote the paper. B.O. PEREIRA, G.-Y. WANG, and M.A.I. SILVA interpreted the data. All authors evaluated and revised the manuscript.

\section{References}

Alckmin-Carvalho, F., Izbicki, S., Fernandes, L. F. B, \& Melo, M. H. S. (2014). Estratégias e instrumentos para a identificação de bullying em estudos nacionais. Avaliação Psicológica, 13(3), 343-350. Recuperado em janeiro 5, 2018, de http:// pepsic.bvsalud.org/ scielo.php?script=sci_arttext\&pid=\$1677-04712014000300006\&lng=pt\&tlng=pt

Associação Brasileira de Empresas de Pesquisa. (2015). Critério de classificação econômica [Criteria for economic classification]. Recuperado em janeiro 5, 2018, de http://www.abep.org/criterioBrasil.aspx

Bandeira, C. M., \& Hutz, C. S. (2012). Bullying: prevalência, implicações e diferenças entre os gêneros. Psicologia Escolar e Educacional, 16(1), 35-44. https://dx.doi.org/10.1590/\$1413-85572012000100004

Batanova, M., Espelage, D. L., \& Rao, M. A. (2014). Early adolescents' willingness to intervene: What roles do attributions, affect, coping, and self-reported victimization play? Journal of School Psychology, 52(3), 279-293. http://dx.doi. org/10.1016/j.jsp.2014.02.001

Brank, E. M., Hoetger, L. A., \& Hazen, K. P. (2012). Bullying. Annual Review of Law and Social Science, 8, 213-230. http:// dx.doi.org/10.1146/annurev-lawsocsci-102811-173820

Craig, W., Harel-Fisch, Y., Fogel-Grinvald, H., Dostaler, S., Hetland. J., Simons-Morton, B., ... Pickett, W. (2009). A crossnational profile of bullying and victimization among adolescents in 40 countries. International Journal of Public Health, 54(Suppl 2), 216-224. http://dx.doi.org/10.1007/s00038-009-5413-9

Cunha, J. M., Weber, L. N. D., \& Steiner Neto, P. (2009). Escala de vitimização e agressão entre Pares (EVAP). In L. N. D. Weber, \& M. A. Dessen (Eds.), Pesquisando a família: instrumentos para coleta e análise de dados (pp.103-114). Curitiba: Juruá.

Del Prette, A., \& Del Prette, Z. A. P. (2005). Sistema Multimídia de Habilidades Sociais de Crianças. São Paulo: Casa do Psicólogo. 
Del Prette, Z. A. P., \& Del Prette, A. (2013). Psicologia das habilidades sociais na infância: teoria e prática. Petrópolis: Vozes.

Due, P., Merlo, J., Harel-Fisch, Y., Damsgaard, M. T., Holstein, B. E., Hetland, J., ... Lynch, P. (2009). Socioeconomic inequality in exposure to bullying during adolescence: A comparative, cross-sectional, multilevel study in 35 countries. American Journal of Public Health, 99(5), 907-914. http://dx.doi.org/10.2105/AJPH.2008.139303

Gasser, L., \& Keller, M. (2009). Are the competent the morally good? Perspective taking and moral motivation of children involved in bullying. Social Development, 18, 798-816. http://dx.doi.org/10.1111/j.1467-9507.2008.00516.x

Grotpeter, J. K., \& Crick, N. R. (1996). Relational aggression, overt aggression, and friendship. Child Development, 67(5), 2328-2338. http://dx.doi.org/10.1111/j.1467-8624.1996.tb01860.x

Hussein, M. H. (2013). The social and emotional skills of bullies, victims, and bully-victims of Egyptian primary school children. International Journal of Psychology, 48(5), 910-921. http://dx.doi.org/10.1080/00207594.2012.702908

Janosz, M., Archambault, I., Pagani, L. S., Pascal, S., Morin, A. J. S., \& Bowen, F. (2008). Are there detrimental effects of witnessing school violence in early adolescence? Journal of Adolescent Health, 43(1), 600-608. http://dx.doi. org/10.1016/j.jadohealth.2008.04.011

Jia, M., \& Mikami, A. Y. (2015). Peer preference and friendship quantity in children with externalizing behavior: Distinct influences on bully status and victim status. Journal of Abnormal Child Psychology, 43(5), 957-969. http://dx.doi. org/10.1007/s10802-014-9956-8

Kochel, K. P., Ladd, G. W., Bagwell, C. L., \& Yabko, B. A. (2015). Bully/victim Profiles' differential risk for worsening peer acceptance: The role of friendship. Journal of Applied Developmental Psychology, 41, 38-45. http://doi.org/10.1016/j. appdev.2015.05.002

Lodder, G. M. A., Scholte, R. H. J., Cillessen, A. H. N., \& Giletta, M. (2016). Bully victimization: selection and influence within adolescent friendship networks and cliques. Journal of Youth and Adolescence, 45(1), 132-144. http://dx.doi. org/10.1007/s10964-015-0343-8

Martins, M. J. D. (2009). Maus tratos entre adolescentes na escola. Lisboa: Editorial Novembro.

Mello, F. C. M., Silva, J. L., Oliveira, W. A., Prado, R. R., Malta, D. C., \& Silva, M. A. I. (2017). A prática de bullying entre escolares brasileiros e fatores associados - Pesquisa Nacional de Saúde do Escolar 2015. Ciência \& Saúde Coletiva, 22(9), 2939-2948. http://dx.doi.org/10.1590/1413-81232017229.12762017

Nansel, T. R., Overpeck, M., Pilla, R. S., Ruan, W. J., Simons-Morton, B., \& Scheidt, P. (2001). Bullying behaviors among U. S. youth: Prevalence and association with psychosocial adjustment. The Journal of the American Medical Association, 285(16), 2094-2100. http://dx.doi.org/10.1001/jama.285.16.2094

Oliveira, W. A., Silva, M. A. I., Silva, J. L., Mello, F. C. M., Prado, R. R., \& Malta, D. C. (2016). Associations between the practice of bullying and individual and contextual variables from the aggressors' perspective. Jornal de Pediatria, 92(1), 32-39. http://dx.doi.org/10.1016/j.jped.2015.04.003

Olweus, D. (2013). School bullying: Development and some important challenges. Annual Review of Clinical Psychology, 9(1), 751-780. http://dx.doi.org/10.1146/annurev-clinpsy-050212-185516

Salgado, F. S., Senra, L. X., \& Lourenço, L. M. (2014). Effectiveness indicators of bullying intervention programs: A systematic review of the international literature. Estudos de Psicologia (Campinas), 31(2), 179-190. http://dx.doi. org/10.1590/0103-166X2014000200004

Salmivalli, C. (2010). Bullying and the peer group: A review. Aggression and Violent Behavior, 15(2), 112-120. https:// dx.doi.org/10.1016/j.avb.2009.08.007

Sampaio, J. M. C., Santos, G. V., Oliveira, W. A., Silva, J. L., Medeiros, M., \& Silva, M. A. I. (2015). Prevalência de bullying e emoções de estudantes envolvidos. Texto \& Contexto Enfermagem, 24(2), 344-352. http://dx.doi.org/10.1590/010407072015003430013

Santos, Z. A., \& Soares, A. B. (2016). Habilidades sociais e bullying: um estudo entre agressores e vítimas. Psicologia Argumento, 34(84), 51-64. http://dx.doi.org/10.7213/psicol.argum.34.084.A005

Seidel, E. J., Moreira Júnior, F. J., Ansuj, A. P., \& Noal, M. R. C. (2008). Comparação entre o método Ward e o método K-médias no agrupamento de produtores de leite. Ciência e Natura, 30(1), 7-15. Recuperado em janeiro 5, 2018, de http://periodicos.ufsm.br/cienciaenatura/article/view/9737/5830

Shin Y. (2010). Psychosocial and friendship characteristics of bully/victim subgroups in Korean primary school children. School Psychology International, 31(4), 372-378. http://dx.doi.org/388.10.1177/0143034310377296

Silva, J. L., \& Bazon, M. R. (2014). Educação escolar e conduta infracional em adolescentes: revisão integrativa da literatura. Estudos de Psicologia (Natal), 19(4), 278-287. http://dx.doi.org/10.1590/S1413-294X2014000400005 
Silva, J. L., Oliveira, W. A., Bazon, M. R., \& Cecilio, S. (2013). Bullying na sala de aula: percepção e intervenção de professores. Arquivos Brasileiros de Psicologia, 65(1), 121-137. Recuperado em janeiro 5, 2018, de http://pepsic. bvsalud.org/scielo.php?script=sci_arttext\&pid=S1677-04712014000300006\&lng=pt\&tlng=pt

Silva, J. L., Oliveira, W. A., Bono, E. L., Dib, M. A., Bazon, M. R., \& Silva, M. A. I. (2016a). Associações entre bullying escolar e conduta infracional: revisão sistemática de estudos longitudinais. Psicologia: Teoria e Pesquisa, 32(1), 81-90. http://dx.doi.org/10.1590/0102-37722016012241081090

Silva, J. L., Oliveira, W. A., Braga, I. F., Farias, M. S., Lizzi, E. A. S., Gonçalves, M. F. C., ... Silva, M. A. I. (2016b). The effects of a skill-based intervention for victims of bullying in Brazil. International Journal of Environmental Research and Public Health, 13(10), 1042-1052. http://dx.doi.org/10.3390/ijerph13111042

Silva, J. L., Oliveira, W. A., Carlos, D. M., Lizzi, E. A. S., Rosario, R., \& Silva, M. A. I. (2018). Intervenção em habilidades sociais e bullying. Revista Brasileira de Enfermagem, 71(3), 1-10. http://dx.doi.org/10.1590/0034-7167-2017-0151

Souza, J. M. (2013). Bullying: uma das faces do preconceito homofóbico entre jovens no contexto escolar (Dissertação de mestrado não-publicada). Universidade Federal de Sergipe. Recuperado em janeiro 5, 2018, de https://ri.ufs.br/ bitstream/riufs/6013/1/JACKELINE_MARIA_SOUZA.pdf

Stan, C., \& Beldean, I. G. (2014). The development of social and emotional skills of students - Ways to reduce the frequency of bullying-type events - Experimental results. Procedia Social and Behavioral Sciences, 114(21), 735-43. http://dx.doi.org/10.1016/j.sbspro.2013.12.777

Yang, A., \& Salmivalli, C. (2015). Effectiveness of the KiVa antibullying programme on bully-victims, bullies and victims. Educational Research, 57(1), 80-90. http://dx.doi.org/10.1080/00131881.2014.983724

Zequinão, M. A., Cardoso, A. A., Silva, J. L., Medeiros, P., Silva, M. A. I., \& Pereira, B.; Cardoso, F. L. (2017). Academic performance and bullying in socially vulnerable students. Journal of Human Growth and Development, 27(1), 19-27. http://dx.doi.org/10.7322/jhgd.127645

Received: May 21, 2018

Final version: May 8, 2019

Approved: July 4, 2019 